\title{
Microbial Quality Assessment and Predominant Microorganism of Biltong Produced in Butcheries in Gaborone, Botswana
}

\author{
Maitshwarelo Ignatius Matsheka1* , Sisai Mpuchane, Berhanu Abegaz Gashe1, \\ Joseph Allotey ${ }^{1}$, Elenimo B. Khonga ${ }^{2}$, Stephan H. Coetzee ${ }^{1}$, Gervas Murindamombe ${ }^{1}$ \\ ${ }^{1}$ Department of Biological Sciences, University of Botswana, Gaborone, Botswana \\ ${ }^{2}$ Botswana College of Agriculture, Gaborone, Botswana \\ Email: ${ }^{*}$ matsheka@mopipi.ub.bw
}

Received 29 June 2014; revised 2 August 2014; accepted 15 August 2014

Copyright (C) 2014 by authors and Scientific Research Publishing Inc. This work is licensed under the Creative Commons Attribution International License (CC BY). http://creativecommons.org/licenses/by/4.0/

cC) (7) Open Access

\section{Abstract}

Biltong is a dried ready to eat meat product that is produced and consumed to a large extent in Botswana. A study was undertaken with the objective of determining the microbial quality and isolating and identifying the predominant bacteria and fungi associated with the small scale production of biltong by local Butcheries. The physico-chemical characteristics of the commercially prepared beef samples were characterized to determine if they had a bearing on the microbial quality. Electron microscopy was used to characterize microbial colonization of the biltong. The total viable count of the biltong samples were found to range from $2-7 \log _{10} \mathrm{cfu} / \mathrm{g}$ with a mean plate count of $8.9 \times 10^{5} \mathrm{cfu} / \mathrm{g}$. About $42 \%$ of the samples had counts higher than $10^{5} \mathrm{cfu} / \mathrm{g}$, which is the recommended upper limit of acceptability as prescribed by the Public Health Laboratory Service guidelines. Bacteria from the genera Staphylococcus and Bacillus were found to be the predominant taxa associated with the biltong, a trend consistent with findings in previous studies on biltong. A total of 14 species were identified from the genus Staphylococcus with $20 \%$ of all bacterial strains identified as Staphylococcus saprophyticus. Four biltong samples were found to comprise Bacillus cereus, a well known food-borne pathogen associated with food poisoning. The predominant moulds and yeasts were found to conform to findings from previous studies conducted on intermediate moisture meat products with the genera Aspergillus, Penicillium and Candida being common. The predominant fungal species were Candida catenulate, Candida pararugosa, Aspergillus restrictus and Aspergillus niger. Some strains of Aspergillus niger are known to produce mycotoxins which compounds the potential risk associated with biltong as a ready to eat meat product.

\footnotetext{
${ }^{*}$ Corresponding author.
}

How to cite this paper: Matsheka, M.I., et al. (2014) Microbial Quality Assessment and Predominant Microorganism of Biltong Produced in Butcheries in Gaborone, Botswana. Food and Nutrition Sciences, 5, 1668-1678. 


\section{Keywords}

\section{Biltong, Contamination, Molds, Aflatoxins, Water Activity, Moisture Content}

\section{Introduction}

Biltong is a ready-to eat meat product comprising of thin strips of dried meat which is spiced. The product is similar to the American dried meat product known as Jerky, but is indigenous to South Africa. The product was developed by the early Dutch settlers as way of preserving meat. Today, biltong as a food commodity has spread as far afield as the United Kingdom, Australia, Portugal, and the United States, partly through the emigration of South African citizens [1] [2]. Biltong can be consumed in its raw as a light snack. Its appeal as a snack has spread to sub-Saharian Africa, including countries like Botswana. Numerous commercial biltong brands are now produced by micro scale industries. Biltong is provided in small attractive plastic packaging in different spiced varieties. These commercial brands have proved popular and are available in almost all convenience and grocery stores.

Over the years the preparation of biltong has evolved according to different cultural practices different. The South African traditional method of preparation involves soaking the meat pieces in apple cider before spicing with coriander, black pepper, salt and brown sugar. This is followed by air dying [3]. Unlike other semi-dried meat products such as salami and cured sausages, microorganisms do not seem to play a role in the development of biltong flavor [4]. The divergence in production is in the spicing, which is used to achieve the unique distinct flavor of the various varieties. Biltong is flavored with various spices and salt and many of the spice formulations are passed on through generations, in home-made biltong [5] or special formulations derived by industries. Flavour and texture are important [6] in the appeal of biltong. Currently, it appears most consumers prefer the moist biltong with water activity $\left(\mathrm{A}_{\mathrm{w}}\right)$ ranging from 0.85 - 0.93 [1] [7].

Meat is being highly nutritional and rich in proteins, consequently serves as a good substrate for microbial growth [8]. Therefore, the expectation is that in its raw state, meat is easily susceptible to colonization by various bacterial flora including fungi. Biltong as a dried meat product has been considered relatively safe in terms of microbial quality. This is with regard of the $A_{w}$ of 0.77 which is considered to be intolerable to most microorganisms and consequently biltong is considered stable from deterioration [9]. However, the fact that biltong as a snack is eaten raw, without cooking, raises questions about its safety. This concern stems from the way the product is processed. Sun drying exposes the meat to contamination from the air, which may contain aerosolized microorganisms, particularly moulds, and spores which being airborne are resistant to drying effects [8]. The drying process may therefore have an effect on the microbial quality of the product at the point of sale.

Previous studies on the microbial quality of biltong have largely been confined to South Africa. Earlier studies have revealed that biltong can serve as a vector for foodborne pathogens such as listeria, salmonella, enterotoxigenic Staphylococci spp and E. coli O157:H7 [3] [10] [13]. This concern has been substantiated by outbreaks of foodborne illnesses associated with the consumption of this product. At least two gastroenteritis outbreaks attributed to Salmonella have been documented in South Africa [14] [15]. Of particular significance is the outbreak in Botswana, in which 17 individuals were affected [16]. Unfortunately due to lack of local capacity in the investigation of outbreaks cases, the causative organism was not determined.

In Botswana, home production of biltong is common, but this practice is more widespread among rural communities due to the lack of refrigeration. Biltong is used as form for the bulk storage of meat. The majority of the population in the rural areas are poor, so plain salt is usually used to aid in the drying process. The meat is subsequently rehydrated by cooking and used as relish to accompany any starch dish (sorghum or maize meal) to make it palatable. Small scale biltong production in local butcheries is also still common practice in Botswana. The product is displayed in an unpacked state on a drying line and bought across the counter after selection by the customer.

Unlike in South Africa, the processing of biltong in Botswana does not involve soaking of meat in cider, the spices are applied directly onto the fresh meat, before solar drying in the open air. This is one of the intricate differences in biltong product production, which may have implications on the microbial quality. Therefore the present study was undertaken to provide information on the microbiological risk of biltong at the point of sale of 
butcheries in Botswana. The specific objectives of the study was to determine the bacterial and mycyological content and to elucidate whether various processing factors such as spices and salting had a bearing on the water activity and overall microbial quality of the biltong. This information would augment the current knowledge on the microbiological hazards associated with commercial biltong and help in establishing processing guidelines to ensure the safe production of biltong at the micro industry level.

\section{Materials and Methods}

\subsection{Sampling Procedure}

Biltong samples displayed on drying lines were bought from supermarkets around Gaborone. Samples were delivered to the laboratory in the plastic bags in which they were wrapped. Samples were examined on the same day, or were stored at $4^{\circ} \mathrm{C}$ in sterilized empty jam jars covered with filter paper and examined the following morning.

\section{Sample Processing}

Using aseptic technique, $10 \mathrm{~g}$ of the sample were transferred into a sterile stomacher bag followed by the addition of $90 \mathrm{ml}$ Ringer's dilution water (1:10 dilution). The sample in the stomacher bag and the diluent were then blended for 120 sec at high speed. Using the 1:10 dilution, serial dilutions were then prepared from $10^{2}$ to $10^{6}$ by transferring $10 \mathrm{ml}$ homogenized sample (1:10 dilution) to $90 \mathrm{ml}$ dilution blank, mixing well with vigorous shaking and continuing until $10^{-8}$ was reached. The $10^{3}$ to $10^{-5}$ dilutions were plated on Nutrient agar for $24 \mathrm{~h}$ at $37^{\circ} \mathrm{C}$ whereas on Potato Dextrose and acidified Corn Meal agar incubation was done at $25^{\circ} \mathrm{C}$ for up to 5 days.

\subsection{Isolation and Purification of Cultures}

After incubation representative colonies were picked from each agar plate. The isolates were purified by several subcultures on Nutrient Agar (NA) for subsequent identification. Strains were maintained and propagated on (NA) slants at $4^{\circ} \mathrm{C}$. This procedure was carried out on subsequent microbiological examination.

\subsection{Identification of Bacteria}

The computerized Biolog system was then used to identify the organisms. The system uses an array of 96 enzymatic reactions to automatically identify each organism from a computerized database by matching the results of the reactions against enzymatic profiles of identified organisms. Gram-positive and Gram-negative bacteria were identified by preparing an inoculum of the culture (of a specific turbidity) according to methods described in the Biolog manual (Biolog Inc., California) and were inoculated in the 96 wells of the Biolog microtitre plates with the inoculum. Incubation of the Biolog plates was for $24 \mathrm{~h}$ at $37^{\circ} \mathrm{C}$, after which the commercial software by Biolog was used for identification.

\subsection{Identification of Fungi}

Isolation and characterization of the fungi was carried out using standard procedures as described by Ceigler A. and Lillehoj E. B. [17], Samson R. A. and van Reenen-Hoekstra E. S. [18] and Elley E. [19]. References were made to Ainsworth G. C., et al. [20] and Samson R. A. and Pitt J. [21].

\subsection{Water Activity Determination}

Samples (2 g) were each finely ground and placed in small containers that were then inserted in the Thermoconstanter, Novosina (Switzerland) for $30 \mathrm{~min}$ after which water activity values were read from the machine. All the samples were analyzed in triplicate.

\subsection{Moisture Content Determination}

Each of the samples ( $2 \mathrm{~g}$ ) were ground and placed in a dry porcelain dish of known weight. The samples were oven dried at $102^{\circ} \mathrm{C}$ for $6 \mathrm{~h}$. There were then put in a desiccator to cool followed by reweighing. The percentage moisture content was then calculated using the following formula: 
$\%$ Moisture Content $=$ weight loss on drying $(\mathrm{g}) \times 100$

weight of sample $(\mathrm{g})$

\subsection{Titrimetric Sodium Chloride Content Determination}

The Mohr method was used for sodium chloride $(\mathrm{NaCl})$ determination. The method involved the use of dilute $(0.1 \mathrm{~N})$ silver nitrate $\left(\mathrm{AgNO}_{3}\right)$ solution as the titrant and $2 \mathrm{ml}$ of potassium chromate $\left(\mathrm{K}_{2} \mathrm{CrO}_{4}\right)$ as the indicator. Titrations were performed to the characteristic yellow-orange end pint of the chromate indicator [22].

\subsection{Electron Microscopy Sample Preparation}

Samples were cut $\sim 1 \mathrm{~cm}^{2}$ from the contaminated surface of the biltong. The bottom of each sample was glued with Leit-C carbon conductive cement onto a $10 \mathrm{~mm}$ pin-type Scanning Electron Microscopy aluminium stub. The samples were then vapour fixed with $\mathrm{OsO}_{4}$ and coated with AuPd as previously described [23]. Each sample was investigated using the XL30 Environmental Scanning Electron Microscope (ESEM) in Low Vacuum (LV) mode.

\subsection{Statistical Analysis}

The Pearson correlation was used to determine if the physico-chemical factors such as moisture content, water activity, and $\mathrm{NaCl}$ content had a relationship with the total viable count. All statistical analyses were performed using the IBM Statistical Package for Social Sciences, SPSS Version 20 for windows (SPSS Inc., Chicago, IL, USA). Value of $\mathrm{P}<0.05$ was used to indicate significance.

\section{Results}

\subsection{Microbial Quality}

The microbial quality of the biltong was determined using the total viable count. The total viable count for all 62 biltong samples was found to range from $2.9 \times 10^{2}$ to $3.3 \times 10^{7} \mathrm{cfu} / \mathrm{g}$ with a mean plate count of $8.9 \times 10^{5} \mathrm{cfu} / \mathrm{g}$. Only one sample fell in the lower end of the $10^{2} \mathrm{cfu} / \mathrm{g}$ and 36 samples (58\%) were found to have count below the $10^{5} \mathrm{cfu} / \mathrm{g}$ which is the recommended limit of microbial safety of ready to eat foods at the point of sale according the to the Public Health Laboratory Service guidelines [24]. A significant proportion (42\%) exceeded this recommended safety limit with 8 samples having counts equal or greater than $10^{6} \mathrm{cfu} / \mathrm{g}$ (Table 1).

\subsection{Microbial Load and Physico-Chemical Parameters}

The mean water activity of the Biltong samples was found to be $0.510 \pm 0.077$, while the mean $\mathrm{NaCl}$ content and moisture content was found to be $5.54 \pm 1.93$ (g/100g meat) and $21.4 \% \pm 7.9 \%$ respectively. To determine if the physico-chemical properties such as moisture content, water activity, and $\mathrm{NaCl}$ content had a bearing on the total viable count, the Pearson correlation coefficient analysis using the various factors was conducted. Of the three factors, the water content was found to have a significant effect (Pearson correlation coefficient 0.29) on the total viable count at $\mathrm{P} 0.05$. The $\mathrm{NaCl}$ content of the biltong was found to have a weak direct negative correlation with total viable count (Pearson correlation coefficient -0.25 ) and was not statistically significant.

\subsection{Electron Microscopy}

From the ESEM investigation it was evident that most of the samples had a clear salt crust formation (Figure 1(a)). The salt did not always cover the entire meat surface. As a consequence of moisture loss during drying, the salt crust cracks due to shrinking. Initial aerial hyphae formation in the saline environment can be seen in Figure 1(b). During the drying cycle cracks in the meat widens to allowing the formation of aerial hyphae more freely from a subsurface terrain (Figure 1(c)). This is followed by a rapid increase of aerial hyphae growth until the surface is covered with fungi (Figure $\mathbf{1}(\mathrm{d})$ ).

\subsection{Diversity and Prevalence of Bacteria}

The predominant bacterial strains colonizing the biltong samples were identified using the Biolog identification 

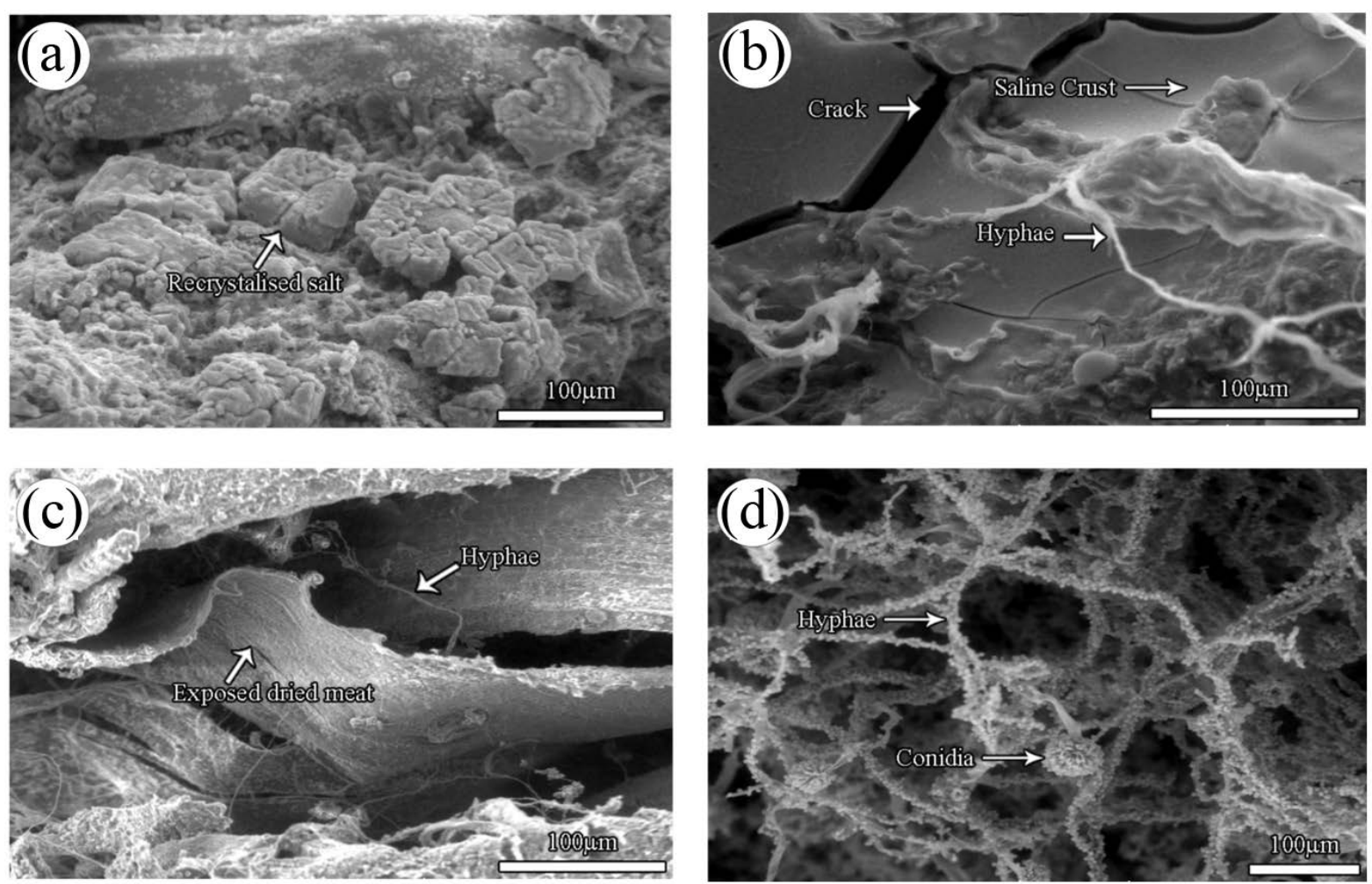

Figure 1. Saline crust formation on biltong during processing (a); the cracking of the biltong during shrinking as a result of the drying process (b); This process continues forming micro-cataclysm, giving access to the subsurface (c); Under these conditions the hyphae multiplies covering the surface (d).

Table 1. Distribution of total viable count among biltong samples.

\begin{tabular}{ccccccc}
\hline Total viable counts cfu/g & $10^{2}$ & $10^{3}$ & $10^{4}$ & $10^{5}$ & $10^{6}$ & $10^{7}$ \\
No of biltong samples & 1 & 16 & 19 & 18 & 6 & 2 \\
\hline
\end{tabular}

system. Overall, 145 of the representative bacterial isolates were found to belong to 35 different species. Although there was great bacterial species variety in terms of all the biltong samples analyzed, most biltong samples had less than three bacterial species per sample. Most of the bacterial isolates where Gram positive bacteria belonging to the genera Staphylococcus and Bacillus. The genus Staphylococcus comprised 55\% of all the bacterial isolates identified, while members of the genus Bacillus made up 19\% of the isolates. Within the genus Staphylococcus, only 11 strains could not be identified to species level (Table 2), while five isolates could not be identified to species level, these belonged to the genera Pseudomonas, Sphingobacterium, Burkholderia, Citrobacter and Aureobacterium respectively. From the genus Staphylococcus, 14 species were identified and the predominant bacterial population was found to be of the species Staphylococcus saprophyticus comprising 20\% of all bacterial strains. The second most frequent member of the group was Staphylococcus arlettae, with a prevalence rate of approximately 7\%. Within the genus Bacillus, Bacillus amyloliqufaciens and Bacillus licheniformis were the most prevalent isolates and were recovered at comparable rates. What was of more significance is that Bacillus cereus, a well recognized food-borne pathogen was isolated from four different biltong samples.

\subsection{Diversity and Predominant Fungal Populations}

Evaluation of the mycobiota revealed a diverse conglomerate of moulds and yeasts with fifty-five different species of fungi identified. Yeast of the genus Candida were the most frequently isolated fungi, with the species Candida catenulate and Candida pararugosa being the most predominant population (Table 3). In terms of prevalence, the genus Candida was sequentially followed by members of filamentous fungi in the genus Asper- 
Table 2. Prevalence of bacterial species isolated from commercial biltong using nutrient agar.

\begin{tabular}{|c|c|c|}
\hline Bacterial species & Number of strains & (\% Prevalence) \\
\hline Staphylococcus saprophyticus & 29 & (20) \\
\hline Staphylococcus spp & 11 & $(7.6)$ \\
\hline Staphylococcus arlettae & 10 & (6.9) \\
\hline Staphylococcus lugdunensis & 5 & (3.4) \\
\hline Staphylococcus klossii & 5 & (3.4) \\
\hline Staphylococcus epidermidis & 5 & (3.4) \\
\hline Staphylococcus haemolyticus & 3 & (2) \\
\hline Staphylococcus capitis & 3 & (2) \\
\hline Staphylococcus gallinarum & 2 & $(1.4)$ \\
\hline Staphylococcus equorum & 2 & $(1.4)$ \\
\hline Bacillus amyloliqufaciens & 8 & $(5,5)$ \\
\hline Bacillus lichenformis & 8 & $(5,5)$ \\
\hline Bacillus cereus & 4 & $(2.8)$ \\
\hline Bacillus halodurans & 3 & (2) \\
\hline Bacillus magaterium & 2 & (1.4) \\
\hline Micrococcus lylae & 6 & $(4.1)$ \\
\hline Micrococcus caseolyticus & 3 & $(2)$ \\
\hline Kyotococcuss sedanterius & 6 & $(4.1)$ \\
\hline Leuconostoc lactis & 2 & (1.4) \\
\hline Enterobacter cloacae & 2 & (1.4) \\
\hline Brevibacterium & 2 & $(1.4)$ \\
\hline${ }^{*}$ Others & 24 & $(16.6)$ \\
\hline Total & 145 & 100 \\
\hline
\end{tabular}

*Others, Bacterial strains isolated once; Staphylococcus lugdunensis, Staphylococcus sciuri, Staphylococcus carnosus, Staphylococcus cohnii, Staphylococcus sciuri ss rodentium, Bacillus coagulans, Bacillus subtilis, Bacillus circulans, Micrococcus luteus, Leuconostoc mesenteroides, Pseudomonas spp, Rhodococcus australis, Sphingobacterium spp, Bulleromyces albus, Burkholderia cocovenenas, Burkholderia spp, Citrobacter spp, Deinococcus radiodurans, Macrococcus bovines, Aureobacterium spp, Moraxella sp (osloensis), Vibrio metschenkovii, Dermacoccus spp, Stomatococcus muciligenous.

gillus and Penicillium. The genus Aspergillus showed the greatest diversity amongst all the fungi with eighteen species identified, while Candida had only eight species and Penicillum seven. Amongst the Aspergilli, Aspergillus restrictus and Apsergillus niger comprised the largest proportion of isolates while unidentified members of the genus Penicillium made up the largest group within the genus. Potato Dextrose agar was more efficient than Corn meal agar in the terms of the number and diversity of fungi isolated. A total of one hundred and twenty one isolates were obtained using Potato dextrose agar in comparison to one hundred and fifteen using Corn meal agar. In terms of fungal diversity forty-three different species were isolated in Potato dextrose agar and twenty-nine in Corn meal agar. Although there was slight concurrence in terms of isolating corresponding species in both growth media, Corn meal agar was more proficient in isolation of yeasts such as Candida famata, Pichia mexicana and Rhodoturula glutinis.

\section{Discussion}

\subsection{Total Viable Count and Microbial Quality}

The efficacy of biltong in extending the shelf life of meat can be assessed by the inhibition of spoilage microor 
Table 3. Fungi isolated from commercial prepared biltong using Potato dextrose and Corm meal agar.

\begin{tabular}{|c|c|c|}
\hline \multirow{2}{*}{ Fungal species } & \multicolumn{2}{|c|}{ Number of Fungi isolated on } \\
\hline & Potato dextrose agar & Corn meal agar \\
\hline Candida catenulata & 12 & 7 \\
\hline Candida pararugosa & 4 & 10 \\
\hline Candida viswanathii & 3 & 6 \\
\hline Candida zeylanoides & 1 & 7 \\
\hline Candida famata & 0 & 12 \\
\hline Candida parapsilosis & 0 & 4 \\
\hline Candida rugosa & 6 & 4 \\
\hline Candida edax & 1 & 1 \\
\hline Aspergillus restrictus & 8 & 10 \\
\hline Aspergillus niger & 6 & 9 \\
\hline Aspergillus auricomus & 5 & 0 \\
\hline Aspergillus niveus & 2 & 1 \\
\hline Apergillus parasiticus & 3 & 0 \\
\hline Apergillus sp & 3 & 1 \\
\hline Aspergillus awamori & 0 & 2 \\
\hline Apsergillus foetidus & 0 & 2 \\
\hline Aspergillus caespitosus & 2 & 0 \\
\hline Aspergillus flavus & 2 & 1 \\
\hline Rhodoturula glutinis & 6 & 11 \\
\hline Rhodoturula aurantiaca & 1 & 4 \\
\hline Penicillium sp & 11 & 5 \\
\hline Penicillium italicum & 2 & 0 \\
\hline Penicillium citrinum & 2 & 0 \\
\hline Penicillium oxalicum & 2 & 0 \\
\hline Penicillium verrucosum & 3 & 0 \\
\hline Pichia mexicana & 5 & 8 \\
\hline Pichia halophila & 2 & 0 \\
\hline Pichia guilliermondii & 1 & 1 \\
\hline Eurotium herbariorum & 5 & 0 \\
\hline Eurotium amstelodami & 2 & 0 \\
\hline Fusarium sp & 3 & 0 \\
\hline Cladosporium sp & 2 & 1 \\
\hline Derbaromyces hansenii & 2 & 0 \\
\hline${ }^{*}$ Others & 14 & 8 \\
\hline Total & 121 & 115 \\
\hline
\end{tabular}

ganisms such as Pseudomonas spp and Lactic acid bacteria. More importantly, an infectious dose of pathogenic microorganisms should be devoid from the food product at the time of consumption. The total viable bacterial count is a microbial parameter which can be used to evaluate the level of contamination by microorganism and consequently can be used to determine if the food is fit for human consumption. In this study, $85 \%$ of the samples had TVC plate counts between the range of $3 \log _{10} \mathrm{cfu} / \mathrm{g}$ and $5 \log _{10} \mathrm{cfu} / \mathrm{g}$. The counts are slightly lower than those recorded for previous studies carried out in South Africa. In early studies carried out by Osterhoff D. R. and Leistner L. [9] and Prior B. A. [4] they documented bacterial plate counts between 5 and $7 \log _{10} \mathrm{cfu} / \mathrm{g}$. This compares well with total viable counts from recent studies carried out by Mhlambi S. G. et al. [17] and Naidoo K. and Lindsay D. [2] that had bacterial counts ranging from 6 - $7 \log _{10} \mathrm{cfu} / \mathrm{g}$ and slightly higher than the 4 - $6 \log _{10} \mathrm{cfu} / \mathrm{g}$ reported by Shale K. and Malebo N. J. [25]. The wide disparity in bacterial viable counts obtained across the various studies suggests that various post slaughter processing factors are responsible for 
bacterial contamination of biltong.

\subsection{The Predominant Biota Associated with Biltong}

The composition of the residual predominant microbiota in food products is also known to be determined by the handling, processing and storage conditions. Interaction of all these predisposing factors could explain the principal bacterial populations associated with biltong in this study. Members of the genus Staphylococcus and Bacillus were found to predominant taxa associated with the biltong, a trend consistent with findings in previous studies conducted in the region [2] [25] [26]. The fore mentioned genera have been found to be predominant in other similar dried meat products [27].

Unlike in other studies carried out by Shale K. and Malebo N. J. [25], Naidoo K. and Lindsay D. [2] and Mhlambi S. G. et al. [11], Staphylococcus aureus, a well-known food-borne pathogen, was not isolated in this study. Our results are similar to that of the previous study by Bokkenheuser [14] in which coagulase negative staphylococci were characterized but no Staphylococcus aureus strains isolated. Staphylococcus saprophyticus was the most frequently isolated bacterial species occurring at a $20 \%$ prevalence rate. Its occurrence in biltong has also been noted in previous studies by Naidoo K. and Lindsay D. [2] and Mhlambi S. G. et al. [11]. Together with Staphylococcus equorum this species has also been isolated frequently from Italian fermented sausages [28]. It is worth noting that an enterotoxin D producing Staphylococcus equorum isolate from biltong has been characterized by Shale K. and Malebo N. J. [25]. Two Staphylococcus equorum strains were also isolated in this current study, although enterotoxin production was not determined.

Among the genus Bacillus, the species Bacillus amyloliquifaciens and Bacillus lichenformis were found to be co-dominant species found on biltong. Bacillus cereus an endospore forming bacteria that is renowned for causing food poisoning [29] was isolated from 4 biltong samples. Bacillus species are known to commonly occur in meat products, but the presence of $B$. cereus in meat cured meats is rarely reported in literature [30]. The incidence of Bacillus cereus in biltong has also been documented by Shale K. and Malebo N. J. [25] in which 90 strains were isolated and further characterized by antimicrobial susceptibility testing. The authors found that some biltong samples had $B$. cereus levels on par with counts associated with actual cases of food-borne illness, although enterotoxin production was not determined. The B. cereus counts in this study ranged from log 3 - 4 cfu/g (results not shown), which falls within the acceptable limits of the Public Health Laboratory Service guidelines [24].

Colonization of food commodities by moulds and yeasts are a common occurrence in post harvest-storage of food products. Species of, Eurutium, Penicillium and Aspergillus are frequently found on the surface of dried cured meat products [27]. Amongst the yeast, the genera Candida, Torulopsis and Debaryomyces are frequently associated with meats [31] [32]. A similar trend was observed in this study whereby the leading genera that was frequently isolated amongst the yeasts was Candida and among the moulds Aspergillus and Penicillium. Candida catenulate and Candida pararugosa were the most common species isolated within the genus Candida while Aspergillus restrictus and Apsergillus niger the predominant species in the Aspergilli. This is the first report highlighting the dominance of these particular species on biltong or an intermediate dried meat product and implies that these species could be the prevalent circulating biota in the local environment and thus the most likely to contaminate meat. In a study conducted by Rahman M. S. et al. [8], they found that the post-drying residual microbial biota was the representation of the initial species complex on the original meat sample. Certain species or strains of Aspergillus, Penicillium and Fusarium are associated with mycotoxin production and the detection in biltong illustrates its potential hazard as a source of mycotoxin intoxication.

\subsection{Physico-Chemical Characteristics and Microbial Quality}

Apart from the availability of nutrients, the survival and growth of microorganisms in foods is determined by extrinsic factors such as temperature, moisture availability and the composition of the gaseous environment. The removal of moisture by drying is an effective strategy for inhibiting microbial growth. The mean water activity of 0.51 of biltong in this study shows suggest that the biltong was extremely dry compared to what is preferred by South African consumers [1]. This could explain why the total viable count for most biltong samples in this in this study, were lower than those in other literature. However, water activity did not seem to have any significant correlation with the total viable count. The salt concentration of $5.54 \%$ falls within the $3 \%-13 \%$ range found in other published studies [33]. High salt $(\mathrm{NaCl})$ concentration had a weak correlation with lower micro- 
bial counts, suggesting that limited salt application can be used to aid in the drying process of biltong. This is in lieu of the negative health effects associated with a high dietary salt intake.

Unless an animal is carrying an asymptomatic infectious disease, fresh meat is theoretically considered sterile at the time of slaughter. However, meat is highly nutritious medium and as a result prone to microbial deterioration. Therefore, it is probable that the observed level of contamination of the biltong in this study reflects on the sanitary conditions of the slaughter house and butcheries, as well as the hygiene practices of the personnel involved in processing of the biltong. As noted by Rahman M. S. et al. [8] the extensive handling of meat during butchering and preparation of strips for drying is an aspect that contributes to high microbial contamination. The presence of Staphylococcus and Bacillus in the biltong samples suggests cross-contamination of the biltong during processing. Possible sources of contamination by could be through the hide of the cattle during slaughter or through hands of the personnel during processing [3]. Human are an important source of Staphylococcus species as they form part of the commensal biota of the nose, throat and skin [34]. The study by Naidoo and Lindsay [2] found that cross contamination of food contact surfaces and hands of retailers to be the source for Staphylococci and Bacillus. Bacillus species normally inhabit the soil and their introduction into biltong could have been raw materials used in the drying process such as spices. Bacillus spp have been associated with spices in dried food products [35]. The high viable bacterial counts of biltong in this study could also be attributed to the fact that the product was sold in unpacked form.

\section{Conclusion}

Although most of the biltong produced in Botswana butcheries was found to be of acceptable quality, the occurrence of pathogenic bacteria such as Bacillus cereus and potential mycotoxin producing fungi such as Apsergillus niger in some samples indicates the latent risks associated with biltong consumption. This study underscores the importance of periodic surveillance of ready to eat food products and confirms the predominant genera of semi-dried meat products. Furthermore, an extensive array of bacterial species and fungi associated with biltong production is documented. This information could be useful in the development of biltong processing. As apart from pathogenic properties, microorganisms play a role in food preservation, organoleptic properties and development of flavor.

\section{Acknowledgements}

We would like to thank the Danish government through Southern African Consortium of Universities in Development \& Environment, Urban and Industrial Areas (SACUDE-UI\&A) for financial support.

\section{References}

[1] Attwell, E. (2003) Biltong Wakes up. Food Review, 30, 11-13.

[2] Naidoo, K. and Lindsay, D. (2010) Potential Cross-Contamination of the Ready to Eat Dried Meat Product, Biltong. British Food Journal, 112, 350-363. http://dx.doi.org/10.1108/00070701011034385

[3] Naidoo, K. and Lindsay, D. (2010) Pathogens Associated with Biltong Product and Their in Vitro Survival of Hurdles Used during Production. Food Protection Trends, 30, 532-538.

[4] Prior, B.A. (1984) Role of Micro-Organisms in Biltong Flavour Development. Journal of Applied Bacteriology, 56, 41-45. http://dx.doi.org/10.1111/j.1365-2672.1984.tb04694.x

[5] Dzimba, F.E.J.M., Joséde Assis, F. and Walter, E.H.M. (2007) Testing the Sensory Acceptability of Biltong Formulated with Different Spices. African Journal of Agricultural Research, 2, 574-577. http://www.academicjournals.org/article/article1380897580_Dzimba\%20et\%20al.pdf

[6] Nummer, B.A., Harrison, J.A., Harrison, M.A., Kendall, P., Sofos, J.N. and Andress, E.L. (2004) Effect of Preparation Methods on the Microbiological Safety of Home-Dried Meat Jerky. Journal of Food Protection, 67, 2337-2341.

[7] Nortje, K., Buys, E.M. and Minnaar, A. (2006) Use of Gamma-Irradiation to Reduce High Levels of Staphylococcus aureus on Casein-Whey Protein Coated Moist Beef Biltong. Food Microbiology, 23, 729-737. http://dx.doi.org/10.1016/j.fm.2006.02.001

[8] Rahamn, M.S., Salman, Z., Kadim, I.T., Mothershaw, A., Al-Riziqi, M.H., Guizani, N., Mahgoub, O. and Ali, A. (2005) Microbial and Physico-Chemical Characteristics of Dried Meat Processed by Different Methods. International Journal of Food Engineering, 1, 1-14.

[9] Osterhoff, D.R. and Leistner, L. (1984) South African Biltong ... Another Close Look. Journal of South African Vete- 
rinary Association, 55, 201-202.

[10] Abongo, B.O. and Momba, M.N.B. (2009) Prevalence and Characterization of Escherichia coli O157:H7 Isolates from Meat Products Sold in Amathole District, Eastern Cape Province of South Africa. Food Microbiology, 26, 173-176. http://dx.doi.org/10.1016/j.fm.2008.10.001

[11] Mhlambi, S.G., Naidoo, K. and Lindsay, D. (2010) Enterotoxin-Producing Staphylococcus Strains Associated with South African Biltong at Point of Sale. Journal of Food Safety, 30, 307-317. http://dx.doi.org/10.1111/j.1745-4565.2009.00208.x

[12] Wolter, H., Laing, E. and Viljoen, B.C. (2000) Isolation and Identification of Yeasts Associated with Intermediate Moisture Meats. Food Technology and Biotechnology, 38, 69-75.

[13] Naidoo, K. and Lindsay, D. (2010) Survival of Listeria monocytogenes, and Enterotoxin-Producing Staphylococcus aureus and Staphylococcus pasteuri, during Two Types of Biltong-Manufacturing Processes. Food Control, 21, 10421050. http://dx.doi.org/10.1016/j.foodcont.2009.12.025

[14] Bokkenheuser, V. (1963) Hygienic Evaluation of Biltong. South African Medical Journal, 37, 619-621.

[15] Neser, A.T., Louw, A., Klein, S. and Sacks, I. (1957) Fatal Salmonella Food Poisoning from Infected Biltong. South African Medical Journal, 23, 172-174.

[16] Tshekiso, I.B. (2002) Overview of Food Safety in Botswana. WHO, Geneva. http://www.who.int/foodsafety/consumer/fos5keysBotswana/en/

[17] Ceigler, A. and Lillehoj, E.B. (1967) Mycotoxins. Advances in Applied Microbiology, 10, 155-219. http://dx.doi.org/10.1016/S0065-2164(08)70192-8

[18] Samson, R.A. and van Reenen-Hoekstra, E.S. (1988) Introduction to Foodborne Fungi. Centraalbureau voor Schimmelcultures, Delft.

[19] Elley, A.R. (1992) Microbial Food Poisoning. Chapman \& Hall, London, 73-91. http://dx.doi.org/10.1007/978-1-4899-3121-4

[20] Ainsworth, G.C., Sparrow, F.K. and Sussman, A.S. (1973) The Fungi, an Advanced Treatise. The Yale Journal of Biology and Medicine, 38, 485-486.

[21] Samson, R.A. and Pitt, J. (1985) Advances in Penicillium and Aspergillus Systemtics. Plenum Press, New York.

[22] Agricultural Research Service (1979) Composition of Foods. U.S. Department of Agriculture.

[23] Coetzee, S.H., Jordaan, A. and Mpuchane, S. (2005) Low Vacuum Mode Combined with OsO 4 Vapor Fixation and Sputter Coating for the Preservation of Delicate Aerial Hyphae and Conidia in the ESEM. Microscopy Research and Technique, 67, 265-270. http://onlinelibrary.wiley.com/doi/10.1002/jemt.20209/abstract http://dx.doi.org/10.1002/jemt.20209

[24] PHLS (2000) Communicable Diseases and Public Health. Public Health Laboratory Service, 3, 163-167.

[25] Shale, K. and Malebo, N.J (2011) Quantification and Antibiotic Susceptibility Profiles of Staphylococcus aureus and Bacillus cereus Strains Isolated from Biltong. Journal of Food Safety, 31, 559-569. http://dx.doi.org/10.1111/j.1745-4565.2011.00335.x

[26] Taylor, M.B. (1976) Changes in Microbial Flora during Biltong Production. South African Food Review, 3, $120-124$.

[27] Sonjak, S., Ličen, S.M., Frisvad, J.C. and Gunde-Cimerman, N. (2011) The Mycobiota of Three Dry-Cured Meat Products from Slovenia. Food Microbiology, 28, 373-376. http://dx.doi.org/10.1016/j.fm.2010.09.007

[28] Mauriello, G., Casaburi, A., Blaiotta, G. and Vallani, F. (2004) Isolation and Technological Properties of Coagulase Negative Staphylococci from Fermented Sausages of Southern Italy. Meat Science, 67, 149-158. http://dx.doi.org/10.1016/j.meatsci.2003.10.003

[29] Granum, P.E. and Lund, T. (1997) Bacillus cereus and Its Food Poisoning Toxins. FEMS Microbiology Letters, 157, 223-228. http://dx.doi.org/10.1111/j.1574-6968.1997.tb12776.X

[30] Matrante, A., Baruzzi, F., Cocconelli, P.S. and Morea, M. (2004) Genotyping and Toxigenic Potential of Bacillus subtilis and Bacillus pumilus Strains Occurring in Industrial and Artisanal Cured Sausages. Applied and Environmental Microbiology, 70, 5168-5176. http://dx.doi.org/10.1128/AEM.70.9.5168-5176.2004

[31] Jay, J.M., Loessner, M.J. and Golden, D.A. (2005) Modern Food Microbiology. 7th Edition, Springer Science and Business Media, Inc., New York, 63-90, 101-125.

[32] Viljoen, J.H., Marasas, W.F.O. and Thiel, P.G. (1993) Fungi Infection and Contamination of Commercial Maize. In: Taylor, J.R.N., Randall, P.G. and Viljoen, J.H., Eds., Cereal Science and Technology: Impact on Changing Africa, Council for Scientific and Industrial Research, Pretoria, 837-853.

[33] Burfoot, D., Everis, L., Mulvey, L., Wood, A. and Campden, R.B. (2010) Literature Review of Microbiological Hazards Associated with Biltong and Similar Dried Meat Products. Food Standard Agency, London, 87. 
[34] Kloos, W.E. and Musselwhite, M.J. (1975) Distribution and Persistence of Staphylococcus and Micrococcus Species and Other Aerobic Bacteria on Human Skin. Applied Microbiology, 30, 381-395.

[35] Banerjee, M. and Sarker, P.K. (2003) Microbiology Quality of Some Retail Spices in India. Food Research International, 36, 469-474. http://dx.doi.org/10.1016/S0963-9969(02)00194-1 
Scientific Research Publishing (SCIRP) is one of the largest Open Access journal publishers. It is currently publishing more than 200 open access, online, peer-reviewed journals covering a wide range of academic disciplines. SCIRP serves the worldwide academic communities and contributes to the progress and application of science with its publication.

Other selected journals from SCIRP are listed as below. Submit your manuscript to us via either submit@scirp.org or Online Submission Portal.
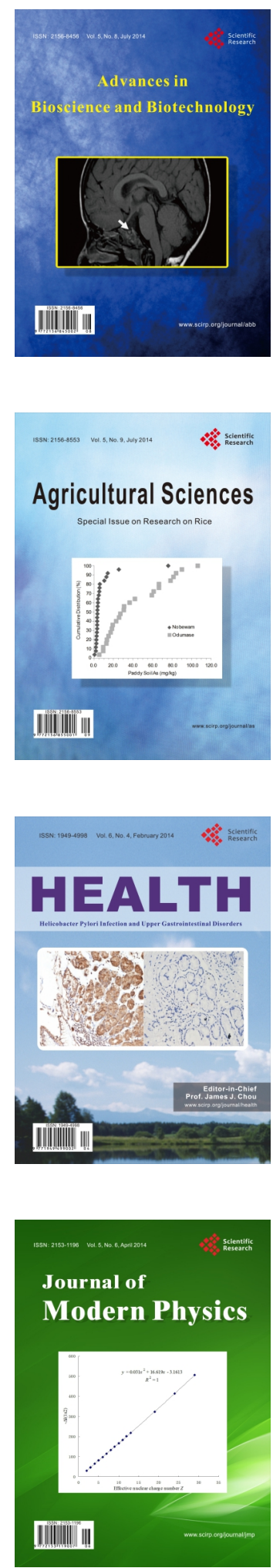
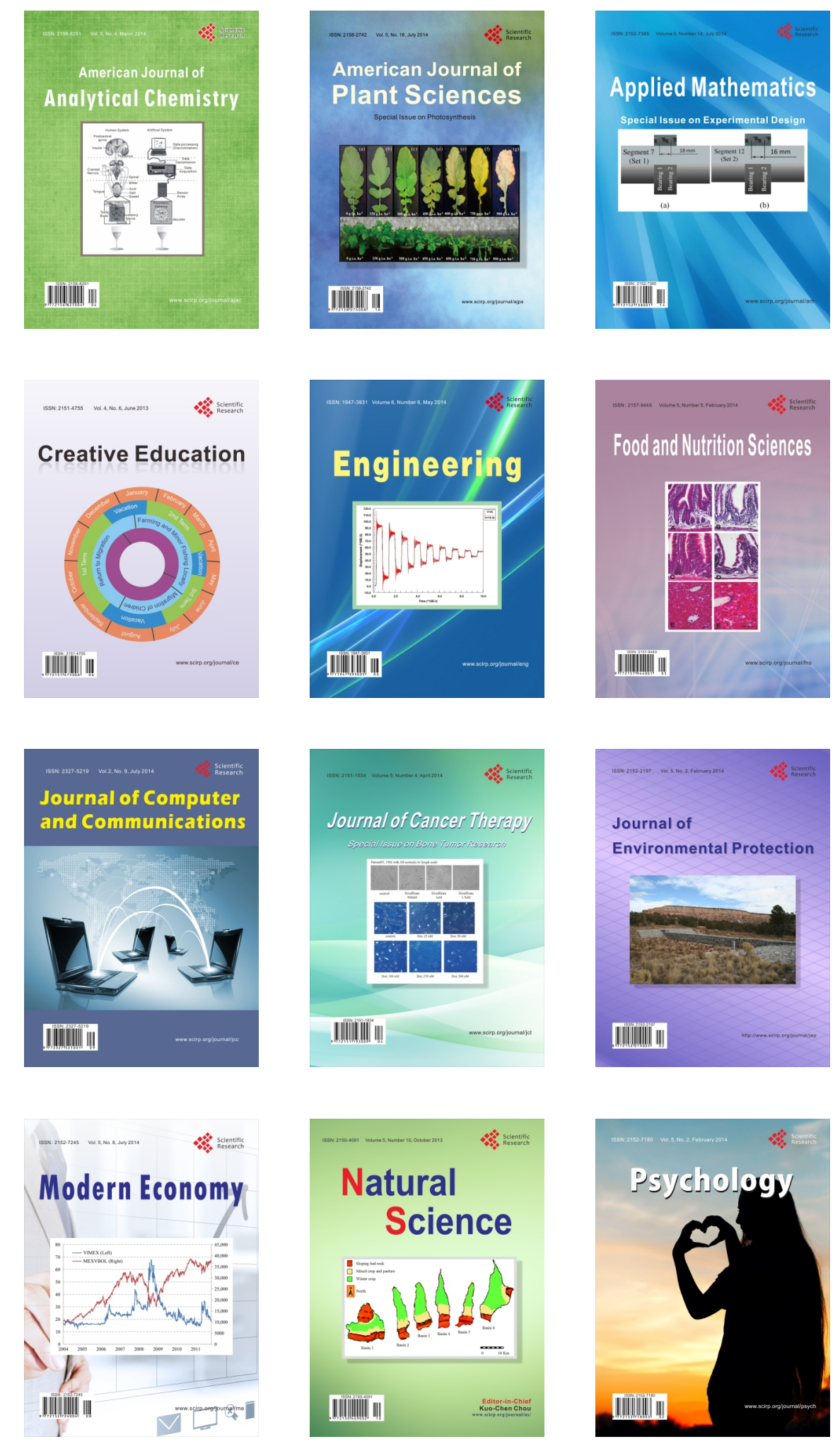